\title{
THE EFFECTS OF ENTREPRENEURIAL BEHAVIOR ON SEAWEED BUSINESS PERFORMANCE IN TAKALAR REGENCY
}

\author{
Siti Hardiyanti Syam*)1, Rachmat Pambudy*), and Wahyu Budi Priatna*) \\ *) Department of Agribusiness, Faculty of Economics and Management, IPB University \\ Jl. Agatis, IPB Dramaga Campus, Bogor 16680, Indonesia
}

\begin{abstract}
Seaweed is one of the main aquaculture products which has high economic value and serves as strategic business opportunities. Seaweed farming becomes the main livelihood for people in Takalar Regency, so it is necessary to improve the working quality of seaweed farmers through the development of entrepreneurial behavior as a new variable in improving the performance of seaweed business. This research is intended to examine the effects of the environment on farmers' entrepreneurial behavior and the effects of entrepreneurial behavior on seaweed business performance. This research takes place in two different production districts, which are Mangarabombang district and Mappakasunggu district, with 150 respondents of seaweed farmers conducted by simple random sampling. The data analysis method used in this research is the Structural Equation Model (SEM) using AMOS 23 software. The result shows that there are insignificant positive impacts of the internal environment on farmers' entrepreneurial behavior as the value of t-statistic is $1.61<1.96$, while there are significant positive impacts of the external environment on farmers' entrepreneurial behavior with the coefficient value of 0.58 and t-statistic of 2.50. The entrepreneurial behavior is found to give significant and positive impacts towards farm performance with the coefficient value if 0.41 and t-statistic of 5.26 $>1.96$. It shows that the development of farmers' entrepreneurial behavior will improve the seaweed business performance in Takalar Regency.
\end{abstract}

Keywords: entrepreneurial behavior, business performance, seaweed, structural equation model

\begin{abstract}
Abstrak: Rumput laut merupakan salah satu produk unggulan perikanan budidaya yang memiliki nilai ekonomis dan strategis sebagai peluang usaha yang menguntungkan. Usahatani rumput laut menjadi mata pencaharian utama bagi masyarakat Kabupaten Takalar, sehingga perlu meningkatkan kualitas kerja para petani rumput laut melalui pengembangan perilaku kewirausahaan sebagai variabel baru dalam meningkatkan kinerja usaha rumput laut. Tujuan dari penelitian ini adalah untuk menganalisis pengaruh lingkungan terhadap perilaku kewirausahaan petani dan pengaruh perilaku kewirusahaan terhadap kinerja usaha rumput laut. Penelitian ini dilakukan di dua kecamatan sentra produksi yaitu Kecamatan Mangarabombang dan Kecamatan Mappakasunggu dengan jumlah responden sebanyak 150 petani rumput laut yang dilakukan dengan teknik simple random sampling. Analisis data menggunakan Structural Equation Model (SEM) dengan bantuan software AMOS 23. Hasil penelitian menunjukkan bahwa lingkungan internal berpengaruh positif namun tidak signifikan terhadap perilaku kewirausahaan karena nilai t-statistik $1.61<1.96 \neg$. Sedangkan lingkungan eksternal pada usahatani rumput laut berpengaruh positif dan signifikan terhadap perilaku kewirausahaan petani dengan nilai koefisien 0.58 dan t-statistiksebesar 2.50. Perilaku kewirausahaan berpengaruh positif dan signifikan terhadap kinerja usahatani dengan nilai koefisien 0.41 dan t-statistik sebesar $5.26>1.96$. Hal ini berarti setiap peningkatan perilaku kewirausahaan petani akan meningkatkan kinerja usahatani rumput laut di Kabupaten Takalar.
\end{abstract}

Kata kunci: perilaku kewirausahaan, kinerja usaha, rumput laut, structural equation model

\footnotetext{
${ }^{1}$ Corresponding author:

Email: titinsyamts@gmail.com
} 


\section{INTRODUCTION}

Seaweed is one of the main aquaculture products which has high economic value and serves as strategic business opportunities. Indonesia has some competitive advantages of seaweed farming because Indonesia is located close to the equator; thus, its climate is entirely tropical and Indonesia has many regions that have good potential for aquaculture businesses. According to FAO (2018), Indonesia is the world's largest producer of Eucheuma cottoni seaweed, with more than 80 percent of market share in which China is the main export destination. Seaweed production is being one of the main export commodities, so it is expected to give value-added for foreign exchange earnings for both countries and the production center areas. Although the current seaweed export is still dominated by raw material product, the government should be optimistic to keep supporting the technical and non-technical development of seaweed commodity in several production center areas to improve the quality and production diversification of seaweed.

The increase of seaweed production growth is fueled by the increase in farmers' interest who choose to cultivate seaweed, in which farmers play the greatest role in seaweed farming. Thus, the provision of competent human resources is essential in developing seaweed production. Rimmer (2010) mentioned that Indonesia has a great potential in seaweed farming but lack of infrastructure and competent workers. Added by Qalsum et al (2018), the main constraint of seaweed production comes from the traditional method used by the farmers who do not take other aspects into account, which are low control and application of technology, inadequate promotion, and limited capital ownerships.

Human resource development is one of the key factors to resolve the problem because in the current Industry 4.0 era, creative, proactive, and adaptive farmers are needed to compete and sustain the business. Supported by Bayu and Eri (2012), they stated that farmer's competency and entrepreneurial behavior are the main determinants for the application of technology. Farmers' who lack entrepreneurial behavior will face difficulties in managing and developing business diversification productively amid the abundant local resources. Hence, seaweed farmers have to be skilled in managing factors of production that they have into a sustained profitable business which have strong competitiveness to deal with huge market pressure. These capabilities will further shape the entrepreneurial behavior.

Studies regarding seaweed have been expanding rapidly that it covers the analysis of business sustainability, supply chain and value-added, competitive and comparative advantages, production efficiency, and marketing. Nonetheless, there is no research done concerning the role of entrepreneurial behavior as an alternative to improve seaweed farmer performance. Dumasari (2014) believed that entrepreneurship is one of the strategic solutions for farmers in managing micro-businesses, which is based on local resources in rural areas. Similar to Darmadji (2012), he also indicated that the entrepreneurial potential of farmers is proven to improve farmers' performance and farm productions. The research outcomes that are applied will be very beneficial for the development of seaweed cultivation as the market keeps growing due to the high market demand. Some studies explicitly and implicitly emphasize the importance of entrepreneurship in farming activities. However, there is still limited empirical evidence that shows the importance of farmers' entrepreneurship as the main actor in on-farm sectors. Therefore, this research is intended to prove the role of entrepreneurial behavior as a new approach in improving farmers' performance, particularly in seaweed production.

South Sulawesi is the largest seaweed producer in Indonesia. Based on the data from the Ministry of Maritime Affairs and Fisheries (2019), the total seaweed production of Indonesia in 2018 is 10,320,255.57 tons, where approximately $30 \%$ of the total $(3,287,893.85$ tons) come from South Sulawesi. Seaweed commodities serve as the main interest in export activities in South Sulawesi, which is supported by the environmental conditions that have great potential in several places in South Sulawesi. Takalar regency is the main contributor to producing seaweed commodities (DKP, 2017). Nonetheless, Takalar Regency still faces some difficulties, specifically in managing human resources. Early research shows that seaweed farmers are still faced with the limitations of postharvest technology, such as the use of para-para tools in the drying process of seaweed that causes the quality that is sold is sometimes not in accordance with the demands of exporters so that the bargaining price of farmers decreases. This will certainly have an impact on the revenue and profits received by farmers. In addition, 
seaweed farmers in Takalar Regency still make dried seaweed (raw material) as their main source of income so that the process of increasing added value into seaweed derivative products has not been done much so that making seaweed commodities in Takalar Regency does not yet fully have a competitive advantage. With these conditions, farmers are still unable to achieve the desired welfare, so it is not surprising that there are a lot of farmers who still live under the poverty line (BPS, 2019).

The problem faced by farmers in doing business is not only due to the pressure of production factors, but also other more influential factors, namely the quality of human resources of farmers which is still relatively low. Thus, progressive efforts for the farmers are needed not only in terms of biological and technical renewal but also in the improvement of local resources such as attitudes/behaviors, values, farmers' capabilities as a whole through an entrepreneurial approach. This is because entrepreneurship is one of the strategic needs of farmers in managing local resource-based farming in rural areas and bearing in mind that farmers have a strategic position as manager of their farming. The intervention of the effects of globalization that enters the real of the living area of rural farming communities requires optimization of the entrepreneurial function, which is expected to be able to direct behavior oriented towards better farming, better business and better living. Based on the research background being described before, the research purpose would be analyzing the effects of internal and external environments on seaweed farmers' entrepreneurial behavior and analyzing the effects of entrepreneurial behavior on seaweed business performance in Takalar regency.

\section{METHODS}

This research takes place in Mangarabombang dan Mapakasunggu districts, Takalar Regency, South Sulawesi. Both districts are chosen because they are the production center areas of seaweed and actively participate in training related to seaweed cultivation conducted by the Ministry of Maritime Affairs and Fisheries and other parties. The data are collected from February to March 2020.

This research utilized primary and secondary data. Primary data are taken from the interview with a Likert Scale questionnaire instrument and observation with the seaweed farmers in Mangarabombang dan Mapakasunggu districts. Secondary data which serve as supporting documents for primary data, it consists of related study of literature from various sources, research, publications, data archives taken from Ministry of Maritime Affairs and Fisheries, Statistics Indonesia (BPS), Provincial Maritime and Fisheries Service (DKP), and Indonesian Seaweed Association (ARLI).

This research applied purposive sampling techniques by determining some criteria and used the SEM method. According to Ferdinand (2002), the sample size needed for applying the SEM model is (1) 100-200, or (2) 5-10 times bigger than the parameters being estimated. As both criteria are used, the respondents consist of 150 seaweed farmers coming from Mangarabombang dan Mappakasunggu districts.

The variables used in this research are latent variables and manifest variables. These variables are commonly used in previous studies and supported by theories that are also appropriate for using SEM analysis. Further explanations about the latent and manifest variables can be seen in Table 1 .

Table 1. Latent variable and manifest variable

\begin{tabular}{ll}
\hline Latent variable & Manifest variable \\
\hline Endogenous & - Optimistic (PK1) \\
latent variable of & - Hard-working (PK2) \\
Entrepreneurial & - Responsibility (PK3) \\
Behavioral & - Innovative-creativity (PK4) \\
(KWU) & - Risk (PK5) \\
& - Decision making (PK6) \\
Exogenous & - Ability (LI1) \\
latent variable & - Interest (LI2) \\
of internal & - Family supports (LI3) \\
environment & \\
internal (LI) & - Pricing (LE1) \\
Exogenous & - Physical environment (LE2) \\
latent variable \\
of external \\
environment & - Government supports (LE3) \\
internal (LE) & - Participation of farmer group (LE4) \\
Endogenous & - Team member performance (LE5) \\
latent variable & - Increase of revenue (KU1) \\
of business & - Competitive advantage (KU2) \\
performance (KU) & - Sales volume (KU3) \\
\hline - Profitability (KU4)
\end{tabular}

Sources: Amir et al. (2018), Heekenda and Chandrakmara (2016), Konte et al. (2019), Nafie et al. (2016), Mulyaningtiyas (2018). 
Structural Equation Model (SEM) techniques are used to test the hypothesis in this research by using AMOS 23 software. This method will resolve the problems that are correlative and regressive and identify the dimensions of a concept as well. Research model development must be based on a strong reasoning process or theoretical justification because the SEM model aims to confirm the existing theories (Waluyo, 2016). This research will develop the model based on Delmar's research, which represents the general model of entrepreneurship and business performance. The data will be analyzed using construct validity, reliability, and Goodness of Fit testing. Then, the researcher will test the causality of the structural model after modifying the model in order to improve the fit.

The hypothesis of this research is based on the condition of innovative product development that requires a supportive environment, several policies must have been issued by the government in order to improve the performance of farmers, but the transfer of knowledge and innovation adoption of seaweed farmers is still relatively low. For this reason, it is necessary to develop human resources as a driving force for development through an entrepreneurial approach. The existence of the entrepreneurial behavior of farmers is expected to be able to make farmers to be more proactive, creative, and innovative in running their farming. So that it encourages farmers to be better able to combine all production factors and collaborate with various parties, it is intended to advance their agriculture and achieve mutual prosperity. Farmer entrepreneurial behavior develops due to internal and external support. The strength of local wisdom and community social capital also influence the growth of entrepreneurial behavior. For this reason, these environmental factors are important to analyze and measure the extent of the effect that is given to a seaweed farmer so that they can foster entrepreneurial behavior that results in improved performance.

Based on these conditions, this research is important to be carried out in order to find out what variables or indicators that most influence the entrepreneurial behavior of farmers, so that entrepreneurial behavior factors can be used as a determinant in improving farm performance. For this reason, this research aims to analyze the influence of the internal, external, and entrepreneurial behavior on the performance of seaweed farming to be carried out in Takalar District. The formulation of a hypothesis that used are (1) the internal environment has a significant and positive effect on the entrepreneurial behavior of seaweed farmers, (2) the external environment has a significant and positive on the entrepreneurial behavior of seaweed farmers, and (3) entrepreneurial behavior of seaweed farmers have a significant and positive effect on the performance of seaweed farming. The concept can be seen in the research framework presented in Figure 1.

\section{RESULTS}

\section{Environmental Factors of Seaweed Farmers}

Internal environmental factors are measured by three indicators, namely ability, interest, and family support. The results showed that the farmer's internal environment was in the high category. The indicator of family support is the most influential factor in supporting the running of farming. This is because the source of labor for the farmers mostly comes from families. Likewise, related to the external environmental factors of seaweed farmers who are also in a very high category, which means the external environment has significant performance and influence for farmers in running their farming. The indicators that measure it are price determination, the physical environmental conditions of government environmental support, the activeness of farmer groups, and the performance of farmer group members. The five indicators have a high average score assessment felt by farmers. Thus, the internal and external environment has a good performance in supporting the sustainability of seaweed farming and is expected to be a shaper of entrepreneurial behavior of seaweed farmers.

\section{Entrepreneurial Behavior of Seaweed Farmers}

Entrepreneurship is a dynamic process, which is always influenced by environmental factors. The entrepreneurial behavior of seaweed farmers is measured by six indicators. The construct of entrepreneurial behavior is reflected by optimism, responsibility, hard work, innovationcreativity, risk-taking, and decision making. The results showed that entrepreneurial behavior was in the very high category, with an average of 4.25 ( $>4.2$ means very high/excellent). It means that seaweed farmers in Takalar Regency have entrepreneurial behavior, but the implementation is still not dominantly applied. Dare to take risks is an indicator that has the highest average among others so that these indicators most strongly measure the variable of entrepreneurial behavior. 


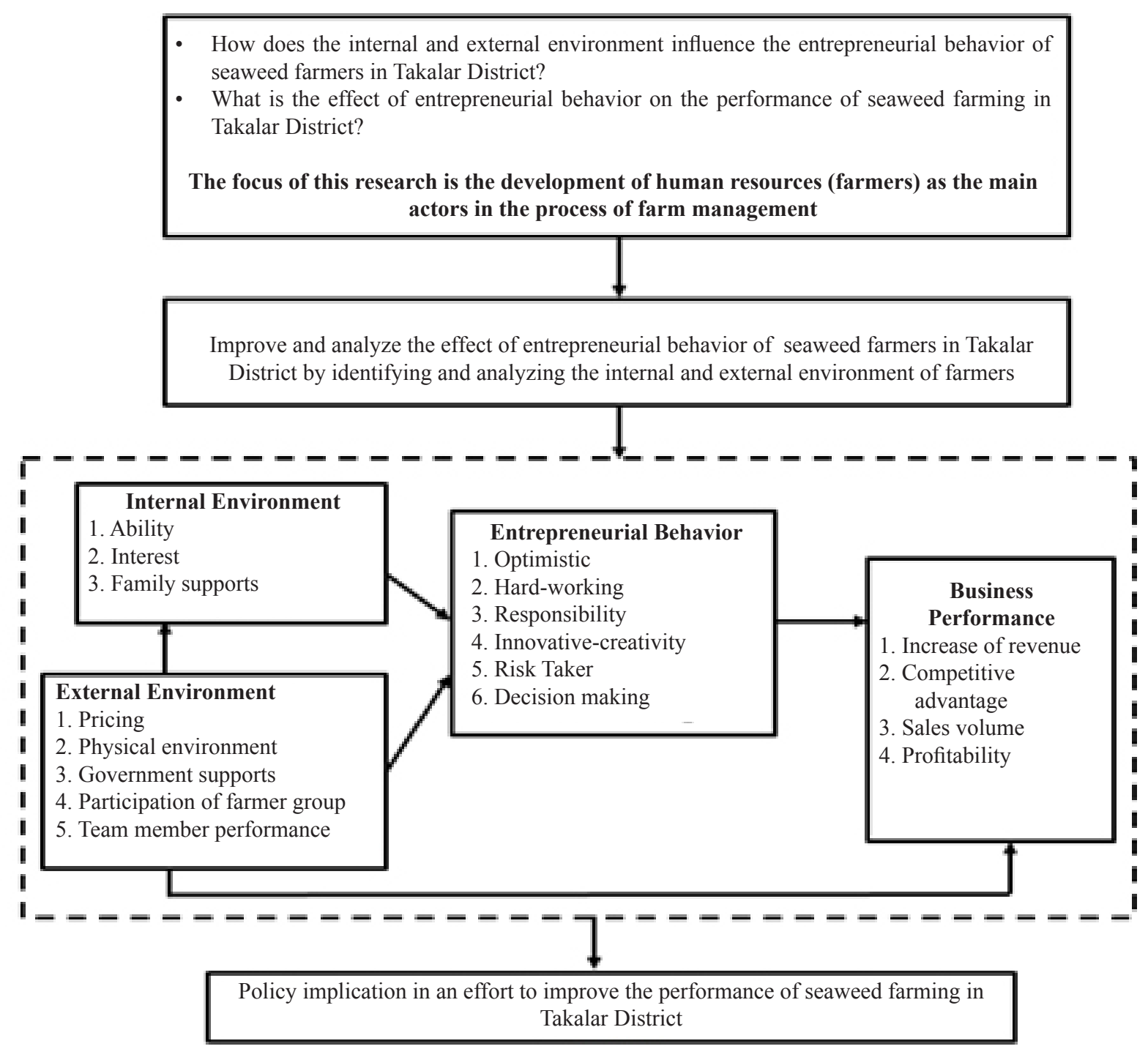

Figure 1. Research framework

\section{Seaweed Business Performance}

The level of performance in this study is farmers' perceptions related to the current condition of seaweed farming, which has experienced significant changes. Four reflective indicators measure the variable performance of seaweed farming. The latent variables of farm performance are reflected through indicators of increased income, competitive advantage, sales volume, and profits. Based on the results, the study note that the average assessment of farmers' perceptions of farm performance is very high at 4.20. It means that the level of performance of seaweed farmers in the study location has increased significantly along with the development of seaweed as a strategic commodity both for domestic needs and export needs. The highest average indicator is the increase in profits, which is 4.34 . It shows that farm performance is the strongest measured by an indicator of increasing profits. In general, the overall percentage of farmers' assessment of research variables, whether internal, external, entrepreneurial behavior to farm performance, is classified as a high category.

\section{Measurement Model (Outer Model)}

Assessment of reflective indicators includes goodness of fit, convergent validity, discriminant validity, and construct reliability tests. The measurement model shows the relationship between manifest variables and latent variables (latent exogenous and latent endogenous). To what extent that the manifest variables measure or reflect each latent variable will be shown by the relationships.

The results of the goodness of fit test of the initial model indicate that the model criteria as a whole did not pass the standard goodness of fit test. Therefore, model modification concerning the provided 
modification indices was conducted, by adding a path between manifest and latent variables and adding error covariances between two error variances (Table 2). After the model modification (Figure 2), SEM analysis showed that all of the manifest variables/indicators and latent variables are appropriate to explain the research model.

\section{Construct Reliability}

The next evaluation test is to calculate the reliability of the indicator. The level of reliability is measured by the value of construct reliability (CR) and the value of variance Extracted (VE). Table 3 shows the value of $\mathrm{CR}$ and VE fulfilling the reliability requirements, which means that the indicator variables have a high consistency in measure the latent variable.
The construct reliability test results indicate the value of each construct is greater than 0.7. Other measurements are also used to assess reliability using VE values. The aim is to measure the level of variance of a construct component that is compiled from its indicators by adjusting the error rate. The results also show that the value owned is greater than 0.5 . Thus, testing the measurement model as a whole has been fulfilled.

\section{Structural Model Analysis (Inner Model)}

The structural model was evaluated using p-value to examine the significance of the coefficient of parameter paths. In determining whether the hypothesis is accepted or rejected, this research used p-value at 0.05 significance level or $\mathrm{CR}$ value $>1.96$ (Kwon et al. 2013).

Table 2. The goodness of fit results of model modification

\begin{tabular}{lccc}
\hline Goodness of Fit & Cut-off Value & Result & Conclusion \\
\hline Chi-Square & Small value & x2 $=108.297$ & Good fit \\
CMIN/Df & Value $\leq 2.00$ & CMIN/Df $=0.976$ & Good fit \\
P-value & Value $\geq 0.05$ & P $=0.555$ & Good fit \\
RMSEA & Value $\leq 0.08$ & RMSEA $=0.000$ & Good fit \\
Goodness of Fit Index (GFI) & Value $\geq 0.90$ & GFI $=0.930$ & Good fit \\
Normed Fit Index (NFI) & Value $\geq 0.90$ & NFI $=0.940$ & Good fit \\
Tucker Lewis Index (TLI) & Value $\geq 0.95$ & TLI $=1.002$ & Good fit \\
Comparative Fit Index (CFI) & Value $\geq 0.95$ & CFI $=1.000$ & Good fit \\
\hline
\end{tabular}

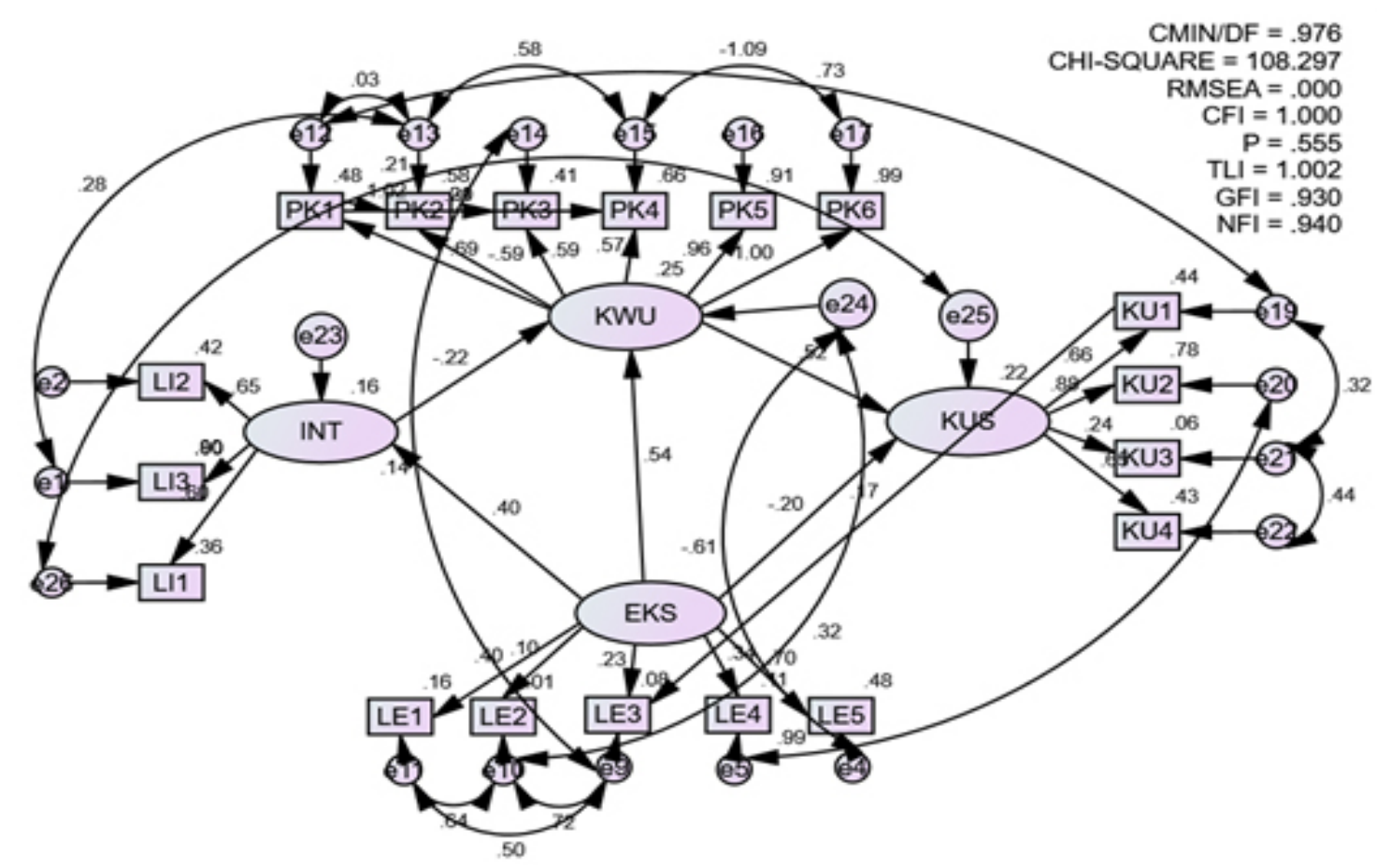

Figure 2. Modification model and estimation results of goodness of fit test 
The Effects of Internal Environment (LI) and External Environment (LE) on Seaweed Farmers' Entrepreneurial Behavior in Takalar Regency

The research findings (Table 4) show that the internal environment affects entrepreneurial behavior in a positive manner, although the correlation is not significant $(1.61<1.96)$. This means the internal influences within seaweed farmers in Takalar Regency do not give any significant impacts on instilling and developing the farmers' entrepreneurial behavior. The insignificant relationship indicates that the indicators of internal environments, which are interest, ability, and family support, do not affect the entrepreneurial behavior for seaweed farmers. Thus, the development of entrepreneurial behavior for seaweed farmers in Takalar is recommended to be done through the external environment.

Based on the real situations in the observed field, the farmers generally have high interests, but they tend not to make a difference if there are not enough stimuli provided. In addition, the farmers, particularly in Punaga village, depending on the neighboring villages, meaning that if the other villages create some innovations, then the farmers from the surroundings will adopt the innovation. In other words, individual factors do not play a significant role in developing seaweed farmers' entrepreneurial behavior. In line with Mulyaningtiyas's (2019) research, it is stated that the internal environment among tilapia farmers does not affect the entrepreneurship significantly. Zainura (2016) also proved that there are no significant effects from individual factors towards entrepreneurship. In this case, it is caused by the low motivation of gayo coffee farmers to adopt new things, which eventually inhibits the development of farmer's entrepreneurial behavior.

Moving to external environment analysis, it showed positive and significant effects on entrepreneurial behavior with the regression coefficient of 0.528 and probability value $<0.05(0.012)$. The higher the level of the external environment, which is represented by pricing, physical environment support, surrounding environment support, participation of farmer group, and team member performance, the higher its effects on entrepreneurial behavior development for seaweed farmers. This finding was supported by the facts from the fields which also showed that supports from the environment such as production tool supplies, seeds from the government, and training related to technical and product processing conducted by seaweed association (UNIDO featured with KKP) are really beneficial for the farmers in expanding farmers' knowledge, skills, and performances. The participation of farmer groups in observed places is also useful for the farmers, not only serves as the place for distributing the supports but also facilitates the flow of information, knowledge, skills transfer processes.

Table 3. Reliability Test for Model

\begin{tabular}{lcccccc}
\hline Variabel Laten & $(\Sigma \text { std Load })^{2}$ & $\Sigma$ ej & $\begin{array}{c}\text { Construct } \\
\text { Reliability }\end{array}$ & $\Sigma(\text { std Load })^{2}$ & $\begin{array}{c}\text { Variance } \\
\text { Extracted }\end{array}$ & Description \\
\hline Internal environment & 4.62 & 0.2 & 0.96 & 1.6 & 0.53 & good \\
External environment & 16.88 & 0.31 & 0.98 & 3.46 & 0.69 & good \\
Entrepreneurial behavior & 16.63 & 0.25 & 0.98 & 2.89 & 0.58 & good \\
Business performance & 7.68 & 0.75 & 0.91 & 2.3 & 0.57 & good \\
\hline
\end{tabular}

Table 4. Estimated value and significance of the structural model

\begin{tabular}{lcccccc}
\hline \multirow{2}{*}{ Variable relationships } & \multicolumn{2}{c}{ Path Coefficients } & \multirow{2}{*}{ t-value } & \multirow{2}{*}{ P-value } & Conclusions \\
\cline { 2 - 4 } & Direct & Indirect & & & & \\
\hline Internal Environment $\rightarrow$ Entrepreneurial Behavior & 0.207 & - & 1.615 & 0.106 & Insignificant \\
External Environment $\rightarrow$ Internal Environment & 0.456 & - & 3.114 & 0.002 & Significant \\
External Environment $\rightarrow$ Entrepreneurial Behavior & 0.580 & 0.88 & 2.502 & 0.012 & Significant \\
Entrepreneurial Behavior $\rightarrow$ Business performance & 0.410 & - & 5.259 & 0 & Significant \\
\hline
\end{tabular}


Another interesting finding from this research is the external environment becomes the latent variable with the highest factor loading in affecting entrepreneurial behavior. Supported by Zainura's (2016) research, it also showed that business climate indications such as farming training give the biggest impacts on entrepreneurial behavior, which includes innovation, risk-taking, perseverance, responsiveness to opportunities, and farmers' independence to improve their business performance. Consequently, as the external environment is the main factor in developing entrepreneurial behavior for seaweed farmers in Takalar Regency, the participation and involvement in farmer groups need to be encouraged.

\section{The Effects of Entrepreneurial Behavioral (KWU) on Seaweed Business Performance (KU) in Takalar Regency}

The variable of entrepreneurial behavior has positive and significant impacts on seaweed business performance in Takalar Regency (CR 5.259). The increase in seaweed farmers' entrepreneurial behavior by 1 percent will increase seaweed business performance by 41 percent. The entrepreneurial behavior refers to the farmers' activities in achieving their goals, which are represented by their optimism, responsibility, hard-working, innovation-creativity, risk-taking, and courage in decision-making traits.

The research showed that business performance would be improved along with the enhancement of innovation and creativity, courage in decision-making and risktaking, optimism, responsibility, and hard-working traits that are consistent and persistent. This is also supported by the environmental conditions that shape entrepreneurial behavior which consequently improves seaweed business performance in Takalar Regency. Consistent with research conducted by Amir et al. (2018), the business performance of cassava processing businesses is affected by entrepreneurial behavior with a coefficient of 0.575. Arnis et al. (2018) also proved that entrepreneurial behavior has a significant positive correlation with the business performance of the salted fish business in Muara Angke. These support the idea of positive impacts brought by entrepreneurial behavior, which can be further applied as the new approach in improving farm business performance. Supported by Dumasari's (2012) research explained that the effects of entrepreneurship potentially promote the creativity for the cassava processing business to seize opportunities by creating products depending on the market trend, variation, interest, and customer expectations. In other words, productivity, creativity, business orientation, and bargaining position are closely related to farmers' entrepreneurship.

The decision-making and risk-taking variables have contributed substantially to developing and representing entrepreneurial behavior. Based on the observation results in the field, seaweed farmers concern about risks related to seaweed cultivation, such as crop failures, fluctuations in price and market demand, and uncertainty in industry requirement. Nonetheless, these risks do not discourage the farmers from continuing their business; instead, they learn their previous mistakes for the betterment in the future. The capability and courage of farmers come from external support, in the form of government support, the physical environment, and benefits from farmer groups that have helped all members who are facing difficulties and make farmers feel confident in carrying out their responsibilities as seaweed farmers.

The hard-working and optimistic traits also play a dominant role in creating entrepreneurial behavior of seaweed farmers. It is proven by the farmers' experiences who have worked for more than ten years; they are optimistic that the development of seaweed business will be profitable thus they tend to keep the hard works and participate in several trainings in order to improve their competency which will eventually result in improvement of business performance. For the creativity and innovation variables, these variables do not fully reflect the entrepreneurial behavior of seaweed farmers in Takalar Regency. In line with the observation results, most farmers have not grasped the market opportunities by providing ready-to-eat seaweed-based food. Although the farmers are interested to add more value to their products, the limitations of capital ownerships, technology application, and marketing hinder them to make progress. Hence, progressive supports in giving opportunities for the farmers to understand and unleash their business potential are needed as they need to use innovation and creativity for sustaining the seaweed business from market dynamics.

Based on the SEM analysis, the entrepreneurial behavior is positively and significantly correlated to business performance, making it is important to improve the farmers' potential to be an entrepreneur. The main factor in improving seaweed business performance in Takalar Regency is the external environment variables, where 
the effects from surroundings such as government, financial institutions, farmer groups, and physical environment as these variables as it affects substantially the development of entrepreneurial behavior and the business performance itself. Government policies which focus on improvement and development of human resources are needed to be further analyzed, in the form of strengthening farmer groups, giving several trainings or educations related to entrepreneurial spirit for SMEs. It is intended to allow the farmers to create product diversification and add more value to their seaweed commodity. Note that seaweed commodity has a lot of derivative products, ranging from food products to medicine-related products. Currently, there are no or very limited business activities that focus on selling processed seaweeds compared to raw products. Therefore, the findings in this research encourage action research to be carried out.

The results of this study are supported by Nurdiani et al. (2015). This research explained that the entrepreneurship level of shallots farmers in Bantul is categorized high with an overall average percentage of $70.87 \%$. The institutional environment factors have the greatest positive effect on individual factors. It means that the presence of institutions plays a role in increasing the entrepreneurial interest of farmers, so that entrepreneurial farmers have a positive effect on farm performance. These results provide evidence of the idea that farmer entrepreneurship through strengthening farmer groups is something that can be grown and can be considered to be a new approach in improving farm performance. The same thing was explained by Heenkenda and Chandrakumara (2016) who showed a significant relationship between entrepreneurial skills and the performance of banana farming in Sri Lanka. The strongest relationship is shown in the variables of collective action and cooperation, readiness for change, innovation, and farm productivity.

The same was stated by Konté et al. (2019) in his research that discusses the determinants of entrepreneurial behavior on agricultural performance among small-scale rice farmers in the Niono zone, Mali. The research shows that entrepreneurial behavior as initiation and innovation. The size of the land, the value of agricultural assets, and marketing access increase agricultural performance by increasing sales and profits. This study concludes that entrepreneurial behavior improves agricultural performance, and the determinants are enforced by other socio-economic and institutional factors of small-scale farmers. This study recommends increasing more entrepreneurial behavior and building a better business environment to drive agricultural businesses towards commercially oriented agriculture.

\section{Managerial Implications}

Based on the research results, the government can accelerate economic growth through an entrepreneurial approach by growing aquaculture business and seaweed cultivator farmers by issuing alternative policies that encourage increased farmers as risk-takers and the growth of creative innovators. Growing innovative and creative farmers through budget allocations for entrepreneurship education and research, facilitating business start-ups for skilled workers, and distributing educated and trained workers (young entrepreneur farmers). Increasing risk-takers through developing business "try-out" centers, fostering a "business link" climate, developing a "risk-taking" culture, creating "soft skills training on risk-taking" programs, and developing small businesses or family businesses.

Furthermore, the government should develop the farmer groups for an educational purpose related to entrepreneurship that facilitates the information transfer regarding seaweed cultivation; thus, farmer groups serve as the medium that productively increases the knowledge, skills, and interest of the farmers. A massive and synergy collaboration, standardized perception, and responsibility between stakeholders, from farmers, traders, exporters, instructors, public figures, and financial institutions such as cooperatives, are needed in realizing the policy. For instance, training related to seaweed nursery, technology application, and improvement in processing the product can be made more intensively and consistently.

\section{CONCLUSIONS AND RECOMMENDATIONS}

\section{Conclusions}

Based on the estimation of a good model, it can be concluded that: Internal factors of farmers do not significantly affect the entrepreneurial behavior of seaweed farmers $(\lambda=0.207 ; \mathrm{t}$-value $=1.615)$. External factors of farmers significantly influence the entrepreneurial behavior of seaweed farmers $(\lambda=$ 0.580 ; $t$-value $=2.502$ ). Indicators that contribute the 
most to reflect the external environment are indicators of activeness of farmer groups $(\lambda=0.944$; $t$-value $=$ $6.210)$ and government environmental support $(\lambda=$ $0.901 ; \mathrm{t}$-value $=6.877)$. The entrepreneurial behavior of seaweed farmers significantly influences the performance of seaweed farming, which indicates that entrepreneurial behavior can be a new variable in improving farming performance $(\lambda=0.410$; $t$-value $=5.259)$. Indicators that dominate in reflecting entrepreneurial behavior are indicators of courage in taking risks and making decisions.

\section{Recommendations}

For further research, a more comprehensive analysis needs to be done to improve farming performance, not only about entrepreneurial behavior but can also add another factor such as farmers' entrepreneurial competencies so that they can see the comparison of entrepreneurial behaviors and competencies owned by farmers.

\section{REFERENCES}

Amir RM, Burhanuddin, Priatna WB. 2018. The Effect of Individual, Environmental and Entrepreneurial Behavior Factors on Business Performance of Cassava SMEs Agroindustry in Padang City. Indonesian Journal of Business and Entrepreneurship 4(1): 1-10.

Arnis N, Baga LM, Burhanuddin. 2018. The Effect of Entrepreneurial Behavior on Salted Fish Business Performance at Muara Angke. Indonesian Journal of Business and Entrepreneurship 4(3): 217-226.

Bayu K danEri M. 2012.Pengaruh Sikap Kewirausahaan dan Kompetensi Petani terhadap Penerapan Teknologi Padi Organik beserta Implikasinya pada Pemanfaatan Potensi Lokal. Artikel Dimuat pada Prosiding Seminar Nasional Improving Performance for Improving Environment. Fakultas Ekonomi. Semarang: FE UNS.

[BPS] Badan Pusat Statistika Kabupaten Takalar. 2019. Statistik Kesejahteraan Rakyat Kabupaten Takalar. https://takalarkab.bps.go.id [10 January 2020].

Darmadji. 2012. Kewirausahaan Petani dan Kinerja Usahatani Cabe dan Padi di Kabupaten Sleman. [disertasi]. Yogyakarta: Universitas Gadjah Mada.
Daryanto A. 2009. Peran Kewirausahaan dalam AgroFood Complex http://ariefdaryanto.blog.mb.ipb. ac.id. [29 May 2020].

[DKP] Dinas Kelautan dan Perikanan Sulawesi Selatan. 2017. Produksi rumput laut provinsi Sulawesi Selatan. http://dkp.sulselprov.go.id/. [3 November 2019]

Dumasari. 2014. Kewirausahaan Petani dalam Pengelolaan Bisnis Mikro di Pedesaan. Jurnal Inovasi dan Kewirausahaan 3(3): 196-202.

[FAO] Food and Agriculture Organization. 2018. The Global Status of Seaweed Production, Trade and Utilization. Vol. 124.http://www.fao.org/3/ CA1121EN/ca1121en.pdf. [16 January 2020].

Ferdinand, A. 2002. Structural Equation Modelling dalam Penelitian Manajemen. Semarang : Badan Penerbit UNDIP.

Heenkenda S dan Chandrakumara D. 2016. Entrepreneurial skills and farming performance: Implications for improving banana farming in Sri Lanka. International Journal of Humanities and Social Sciences 7(1): 14-26.

Konté et al. 2019. Effect of Entrepreneurial Behaviour on Farm Performance among Small-scale Farmers: Case of Niono Zone, Mali. Journal of Advances in Agricultural Science 7(1): 24-39.

[KKPRI]KementerianKelautandanPerikanan Republik Indonesia. 2019. Kelautan dan perikanan dalam angka tahun 2018. http://sidatik.kkp.go.ids. [1 November 2019].

Kwon M, Kim DJ, Cho H, Yang S. 2013. Development and Validation of a Smartphone Addiction Scale (SAS). Jounal open Acces Freely available online. 8(12): e83558.

Mulyaningtiyas RD. 2018. Aplikasi Structural Equation Modelling (SEM) Pada Kajian Pengaruh Kelembagaan: Modal Sosial Jiwa Kewirausahaan Terhadap Kinerja Usaha Budidaya Ikan Nila di Kabupaten Sleman. Jurnal Tekno Sains 7(2): 83154.

Nurdiani et al. 2015. Farmers Entrepreneurship and Performance of Red Onion Farming. Journal of agricultural science. 18(2): 98-108.

Qalsum U, Adhi AK, Fariyanti A. 2018. Pemasaran dan Nilai Tambah Rumput Laut di Kabupaten Takalar, Provinsi Sulawesi Selatan. Jurnal Ilmiah Manajemen 8(3): 541-561.

Rimmer MA. 2010. Maricultural development in Indonesia: prospect and constraint. Indonesian Aquaculture Journal 5(2): 187-201.

Waluyo, Minto. 2016. Mudah Cepat Tepat Penggunaan 
Tools AMOS Dalam Aplikasi (SEM). Surabaya: UPN Veteran.

Zainura U, Kusnadi N, Burhanuddin. 2016. Perilaku
Kewirausahaan Petani Kopi Arabika Gayo di Kabupaten Bener Meriah Provinsi Aceh. Jurnal Penyuluhan 12(2): 126-143. 